\title{
A Study of Teachers' Attitudes Towards the Education of a Child with Physically Impairment Students at the Higher Secondary Level
}

\author{
Akhilesh Yadav \\ Department of Education, Central Institute of Education, University of Delhi, Delhi, India \\ Email address: \\ akhileshyadav.edu@gmail.com, ayadav@cie.du.ac.in \\ To cite this article: \\ Akhilesh Yadav. A Study of Teachers' Attitudes Towards the Education of a Child with Physically Impairment Students at the Higher \\ Secondary Level. Teacher Education and Curriculum Studies. Vol. 5, No. 2, 2020, pp. 14-21. doi: 10.11648/j.tecs.20200502.11
}

Received: September 8, 2019; Accepted: October 16, 2019; Published: May 18, 2020

\begin{abstract}
In this research, has done on topic of "A Study of teachers' attitude towards the education of child with physically impairment students at higher secondary level”. Population of research decided on 32 higher secondary level 316 teachers. In which selected sample of research 20 higher secondary school of 100 teachers. The sample has selected, using of simple systematic random sampling technique. Self-made teacher attitude measurement questionnaire has used to collecting of data. In the form of statistical analysis have used of mean, standard deviation, Kai-test and T-scale statistical techniques. Statistics will be added based on the results obtained after the analysis that physically disable student his/her education toward attitude of teachers of the secondary level of the normal for students as well as ever. In research, find positive about the female teacher's attitude toward education of child with physically impairment students than male teachers. And also find to the research government school teacher positive attitude toward the education of child with physically impairment more than private school teacher attitude. More result finding research in no attitude difference between government school female teachers and private school female teachers. Last, conclude of research to more sensitization of teacher toward the education of child with physically impairment.
\end{abstract}

Keywords: Disability, Student, Attitude, Teacher, Education, Physical

\section{Introduction}

Negative attitudes towards people with a disability can become a barrier to their inclusion in schools, at work and in the general community. Various investigations have shown that, especially from the point of view of experts (teachers, psychologists, therapists etc.), the quality of life of such individuals will be affected. Examining the perspectives of different categories of experts for those with a disability helps us understand the interactions of nature between these groups. To strengthen the relationship between training approaches and mutual professionalism to strengthen relationships, to promote equal opportunities and active participation when ideas are being identified in social life. Some measures can be taken. Researcher [4] define attitude towards members of a particular group as "an attitude (usually negative), based exclusively on the fact that they belong to the particular group". Attitude have a different meaning from discrimination, for the reason that discrimination involves actions (usually negative) that target individuals of a particular group. As an approach, bias acts like other cognitive forms and it is assumed that information supporting bias is indicated in the approach and more so than information [12]. The bar is communicated which is not and therefore, it is saved more rapidly in the brain. In the realm of attitude, prejudices, social representations justify the activation of social stereotypes, which, in turn, are expressed at the level of behavior, which also reproduces related social representations [11]

A normal person does justice to a person with a disability according to their attitude, prejudices and stereotypes (positive or negative). Researchers have proved the important role of teachers' behavior in their class with students with disabilities [8, 30]. It describes the attitudes and perceptions they make themselves towards those individuals [18]. Teachers 'positive attitude toward people with disabilities and 
their willingness to positively and effectively handle children's individual differences in the classroom affect both parents' and children's perspectives without disabilities as well as the success of educational inclusion [16].

The role of the teacher in the education of children with disability is important and attitude of the teacher in the classroom process of inclusive education discharges the important role. The teachers do not ask questions from the children with disability students and he does not check their housework in the same way as other students, this kind of behavior pushes the children to exclusion. This type of teacher's attitude and behavior creates difficulties in the formation of inclusive education and successful operation [24]. The teacher's attitude and behavior are sympathetic to children with disability students. By which the teacher considers this type of student to be weak to others, or to say that it is worth noting that even when these children are in the classroom, they find themselves separated from the class. Most teachers adopt sympathetic views towards students like disable and other such students. Even then, in general view today, ignorance-neglected children with disability. Even though children with disability is weak from the physical point of view, but her brain is mature such as normal children. For this type reason, efforts should make to connect the unstable divisions to the mainstream of the society, through the schemes and programs run by studying social-economic problems and rehabilitation. Therefore, that can spend their lives as normal people [29].

Definition of Physical Disability: - Physical disability means that it is a Divine body which is physically disability meaning that someone encounters difficulty in seeing, speaking, listening or walking, we will share physical disability in four parts. 1. Person with visual impairment 2. Person with voice impairment (Deaf) 3. Person with Hearing impairment 4. Person with loco-motor impairment [24].

Literacy status of person with disability in India's literacy rate is only 55 percent ( 1.46 million) in comparison with 73 per cent, which is the lowest state in terms of 62 per cent male literacy rate and 45 per cent female literacy rate in the ratio of national literacy rate, indicating their poor state of education. If you talk about reaching school, then in total 5 to 19 years, only 57 per cent of children and 47 per cent of girls in the of the world. The Dry of the total population of 2.68 million, 11 per cent are below primary education, 12 per cent have access to primary education, 9 per cent have access to secondary education and only 3 per cent of the students reach graduate education [24]. These figures write down to us that this society is still backward educationally even from the main society.

\subsection{Need and Importance of Research Studies}

The need for a research topic is also that as the teachers' attitude in education of child with impairment students is a major obstacle, these students are the main obstacle in getting education in inclusive education [26]. The attitude of teachers is the main obstacle for teaching for students with disability, and most teachers are not in favor of joining these students in the classroom [7]. Teachers should adopt empathy rather than sympathy, so that such students do not separate him from the other students in the classroom, empowered full sense of vision to become equal to the other students. It is helpful technique for teaching children with disability [14].

The need for a research is also that the students of higher secondary level are in adolescent stage, which is the most important duration of his life, at this level, teacher work is not limited to teaching only, but the role of guiding is too pursue. Child's vocational, personal and social direction is required at this stage of age, because they are going through the toughest phase of their life part. Where role of teachers increases even more, because the teacher is the only, which can provide the right direction to their life by giving proper vocational, personal and social guidance to the children.

This study is also important because it is important for a teacher to behave and interfere with the teaching of divine and obstruction in participation. Nature is the basis of human life our tendency clearly affects, our thoughts feelings and whatever we do [21]. They really decide to think, feel and act on us, the tendency is in fact ready to do any work, but this is very emotional, as it is how we evaluate people and things. Reflects on it, it guides us in making this decision, which we like or dislike whom to survive and whom to adopt. The biggest obstacle is the attitude of the teacher, if the teacher has a negative attitude towards a child with a specific need, or if such child is negative for his education, the inclusion cannot be successful, the teacher's behavior is also a teacher program. Knowing the experience of workshops and other people in this area is change.

The researcher has found out through this study that how the attitude of teachers affects the education of children with disability. The school plays an important role in adjusting the general and physical impairment students. Similarly, teachers work as an internal inspiration for students, but the adjustment is an earning factor. That is why it does not always remain the same for everyone, because every person is different, so its adjustment will also be different. If a child with a disability affects the child negatively, then there is the effect of negativity in his behavior and development. By detecting the reasons responsible for the teachers' attitudes, those who are obstructing their education and motivation can overcome.

\subsection{Research Objective}

1. Study of Teacher attitude towards education for child with physically impairment at the higher secondary level.

2. To comparative study teacher attitude towards education for child with physically impairment at the higher secondary level.

\subsection{Research Hypothesis}

1. The attitude of the teachers at the higher secondary level government school is normal toward a child with physically impairment her education. 
2. The attitude of the teachers at the higher secondary level nongovernment school is normal toward a child with physically impairment her education.

3. The female teacher's attitude of schools of higher secondary level is normal to children with physical disability.

4. The male teacher's attitude of schools of higher secondary level is normal to children with physical disability.

5. There is no significant difference between government and non-governmental teacher attitude towards education of children with physical disability.

6. There is no significant difference between male and female teacher attitude towards education of children with physical disability.

7. There is no significant difference between government male teacher and non-governmental male teacher attitude towards education of children with physical disability.

8. There is no significant difference between government female teacher and non-governmental female teacher attitude towards education of children with physical disability.

\section{Review of Literature}

Aden, Hardeep and A. McCarthy. (2014) presented the research on the topic "Current Attitude for People with disability", in which research find to the $53 \%$ of the people of the British population said that they feel disquieted with living and working with the people with disability. Moreover, $47 \%$ of people said that there is discomfort in living with them, but there is no discomfort in working with them. Martin, A. R. \& Emilio A. A. (2013) in the result of the "Development and Validation of a Scale to Identify the Attitude toward Disability toward in higher education". It found that teachers and students per normal, as well as found that each psyche provide evidence of quality (psychometric). Grams, Molly and C. Leverentz (2010) research the topic "Attitude toward the Person with Disability in Comparison between China and American Students", as a result, the social vision angle is negative for the people with disability, as well as American Students compared to the Chinese students, positive attitude towards disability was fined. Flinders, Layera (2007) researches the topic "The Multidimensional attitudes scale towards person with disability" it research created a tools measure for attitude. Krahe, Barbara and C. Altwasser, (2006) "Changing the negative attitude toward Person with physical disability. It is an experimental study. Rix (2009) find out his research, more teacher attitude towards children with disability has normal attitude, mean sixty percent teacher attitude toward children with disability has average. Penna (2008) finding his research to male teacher attitude toward normal, but female teacher attitude toward children with disability to positive. Vignes et al. (2009) found his research to a positive correlation between parent's attitudes toward person with disability and his children's view on person with disability. Roberts and Lindsell (1997) highlighted his research that those children's attitudes and perceptions towards various disabilities - especially as for pre-schooling children - are influenced at an early stage by their mothers' attitudes and perceptions towards these disabilities. Avissar, Reiter \& Layser (2003) teachers' attitudes and perceptions towards persons with disability are affected by many factors, such as their gender, age and educational experience, the experience of dealing with person with disability, their preparation and education as well as their beliefs. Eichinger, Rizzo \& sirotnik (1991) shown his research to that female teachers have a more positive attitude towards the inclusion of children with disability, compared to male teachers. Al- Faiz (2007) describe his research that teachers who had a thorough educational experience and interaction more with person with disability, had more positive attitude towards the inclusion of children with disability, compared to teacher with less education experience and interaction with person with person with disability. Valchou (2014) has shown his research that even though some teachers believe that a child with a disability has the right to equal educational opportunities, their attitudes towards its inclusion are however, frequently negative and affect the result of its inclusion in the education or class. Anke de Boer, Sip Jan Pijl, Wendy Post and Alexander Minnaert (2012) founded his research to The teachers' attitudes had a negative impact on students' attitudes, whereas parents' attitudes had a positive impact. All research indicates to gender, educational experience, professional experience effect of attitude toward children with disability. And some research funded teacher belief effect of his attitude. Its many causes of development of attitude, and many reason different between male teacher attitude and female teacher attitude such as female has more emotional attachment quality rather than male person.

\section{Research Methodology}

Conducted from the objective, reliable, non-partisan and bias to the research work and from a scientific perspective, the researcher has used the survey method of descriptive research. The sample selection has done by using the lottery method under simple random sampling as the method of selection of samples in this research. Because the population is limited here, therefore the lottery method has used as the method of retention. The selected teachers in each pattern have been selected based on of their seniority (senior, lower senior) order. In the form of sampling of 316 teachers of 32 secondary levels selected as sample, 100 senior teachers of 20 senior secondary schools have selected. In order to study the research problem presented, the 'self-made questionnaire' has used by the finder as a measurement tool. In which the total number of questions is 50. There are 27 negative questions and 23 positive questions in these 50 questions. This questionnaire has 
created according to the Linkart method. This method falls under the scaled reaction method of attitude measurement technique. Divided of questionnaire after finding to data, five alternatives to respond to the questionnaire-as very agree, some agree, uncertain, some disagree, very disagree have been used. The reliability of the submitted test has known by the use of the half method in the semicolon reliability method. The above reliability coefficient of the above test has been 0.52 and validity coefficient 0.631 . In the research, researcher use of statistics of mean, standard deviation, t-test and Kai-square.

Table 1. Hypothesis and level of significant and significant values.

\begin{tabular}{|c|c|c|c|}
\hline Sr. No & Hypothesis & t-test/K-square & Significant level \\
\hline 1. & $\begin{array}{l}\text { The attitude of the teachers at the higher secondary level government school is normal toward } \\
\text { a child with physically impairment her education. }\end{array}$ & $1.60^{\#}$ & $\begin{array}{l}\text { No significant on the } 0.05 \\
\text { level }\end{array}$ \\
\hline 2. & $\begin{array}{l}\text { The attitude of the teachers at the higher secondary level nongovernment school is normal } \\
\text { toward a child with physically impairment her education. }\end{array}$ & $6.00^{\#}$ & $\begin{array}{l}\text { Significant on the } 0.05 \\
\text { level }\end{array}$ \\
\hline 3. & $\begin{array}{l}\text { The female teacher's attitude of schools of higher secondary level is normal to children with } \\
\text { physical disability. }\end{array}$ & $2.33^{\#}$ & $\begin{array}{l}\text { No significant on the } 0.05 \\
\text { level }\end{array}$ \\
\hline 4. & $\begin{array}{l}\text { The male teacher's attitude of schools of higher secondary level is normal to children with } \\
\text { physical disability. }\end{array}$ & $10.20^{\#}$ & $\begin{array}{l}\text { Significant on the } 0.01 \\
\text { level }\end{array}$ \\
\hline 5. & $\begin{array}{l}\text { There is no significant difference between government and non-governmental teacher attitude } \\
\text { towards education of children with physical disability. }\end{array}$ & $0.25^{*}$ & $\begin{array}{l}\text { No significant on the } 0.05 \\
\text { level }\end{array}$ \\
\hline 6. & $\begin{array}{l}\text { There is no significant difference between male and female teacher attitude towards } \\
\text { education of children with physical disability. }\end{array}$ & $1.15^{*}$ & $\begin{array}{l}\text { No significant on the } 0.05 \\
\text { level }\end{array}$ \\
\hline 7. & $\begin{array}{l}\text { There is no significant difference between government male teacher and non-governmental } \\
\text { male teacher attitude towards education of children with physical disability. }\end{array}$ & $1.42^{*}$ & $\begin{array}{l}\text { No significant on the } 0.05 \\
\text { level }\end{array}$ \\
\hline 8. & $\begin{array}{l}\text { There is no significant difference between government female teacher and non-governmental } \\
\text { female teacher attitude towards education of children with physical disability. }\end{array}$ & $0.33^{*}$ & $\begin{array}{l}\text { No significant on the } 0.05 \\
\text { level }\end{array}$ \\
\hline
\end{tabular}

${ }^{*}$ kais-test value, ${ }^{*}$ t-test value

\section{Finding of the Results}

After the data calculating from the research presented and their analysis, the following results have received:

1. To founded general attitude towards the education of the child with disability students of the teachers at the higher secondary level government schools has received. This is display to the students; those teachers of government high school level, have similar attitude like normal students.

2. To find out general attitude towards the education of the child with disability students of teachers for nongovernment schools has received in general. This is display to the students, that the teacher at government high school level have similar attitude like normal students.

3. To founded female teachers, have general attitude towards children with disability students at senior secondary level schools received. It is display to the students, that the senior secondary level female teachers have similar attitude like general students.

4. To founded, general attitude of the male teachers towards the education of the child with disability students at higher secondary level schools has received. It is display to that the senior secondary level teachers have similar like general students for child with disability students, as well as if the teacher is trained; the effect of gender is not reflecting on the attitude towards the children.

5. There is no significant difference between the senior secondary government and non-government teachers. By which display if the teacher is train then there is no difference in the teacher's attitudes due to being governmental or non-governmental.

6. There is no significant difference between the intervention of the education of the child with disability students of senior secondary level male teachers and female teachers. From which it is indicate, that there is no difference between the teachers' attitudes due to the separation of the teacher gender.

7. There is no significant difference between the senior secondary level government and non-government men teachers, which shows that if there are different types of schools on the same type of gender, in the teacher's attitude is no difference.

8. There is no significant difference between the senior secondary level government and non-government women teachers. By which it is display that there is no difference in the attitude between teachers, because of having different types of schools on being the same gender.

\subsection{Main Discussion of Results}

Following the collection and analysis of data in research, the main results have achieved:

1. Such as a result of the research, it found that $17 \%$ of teachers received more than 200 reactions, $53 \%$ of the teachers received reactions between 150 and 200, and 30 percent of teachers received forever than 150 marks. That is, the $17 \%$ teacher's attitude of in the higher category, 53 percent teachers' attitude in general category, 30\% teachers' attitudes found in the lower attitude category. 


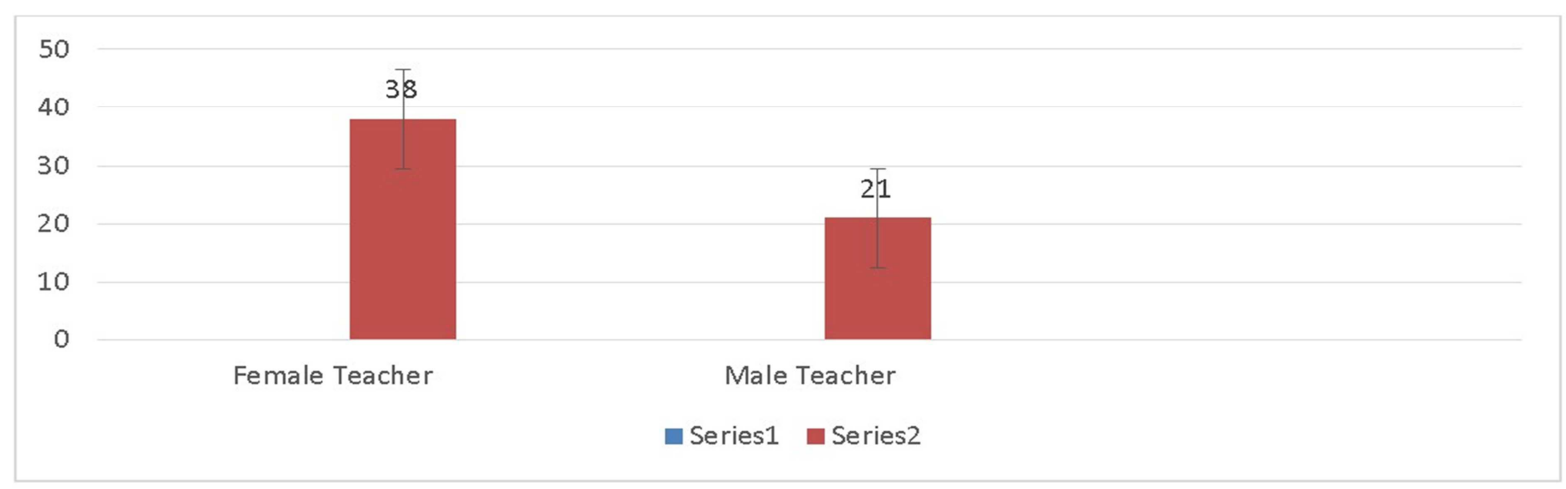

Figure 1. The graph showing percentage and number of teacher attitude category according to gender.

2. Because of research, it found that $68 \%$ (68 teachers) teachers' attitude positive and 32\% (32 teachers) teachers got negative attitude. In which $70 \%$ of the government school (35 teachers) teachers 'aptitude positive and $30 \%$ (15 teachers) teachers' apathy received negative. Non-government school's teachers $32 \%$ (16 teachers) have positive attitude and $68 \%$ of teachers (34 teachers) have a negative attitude.

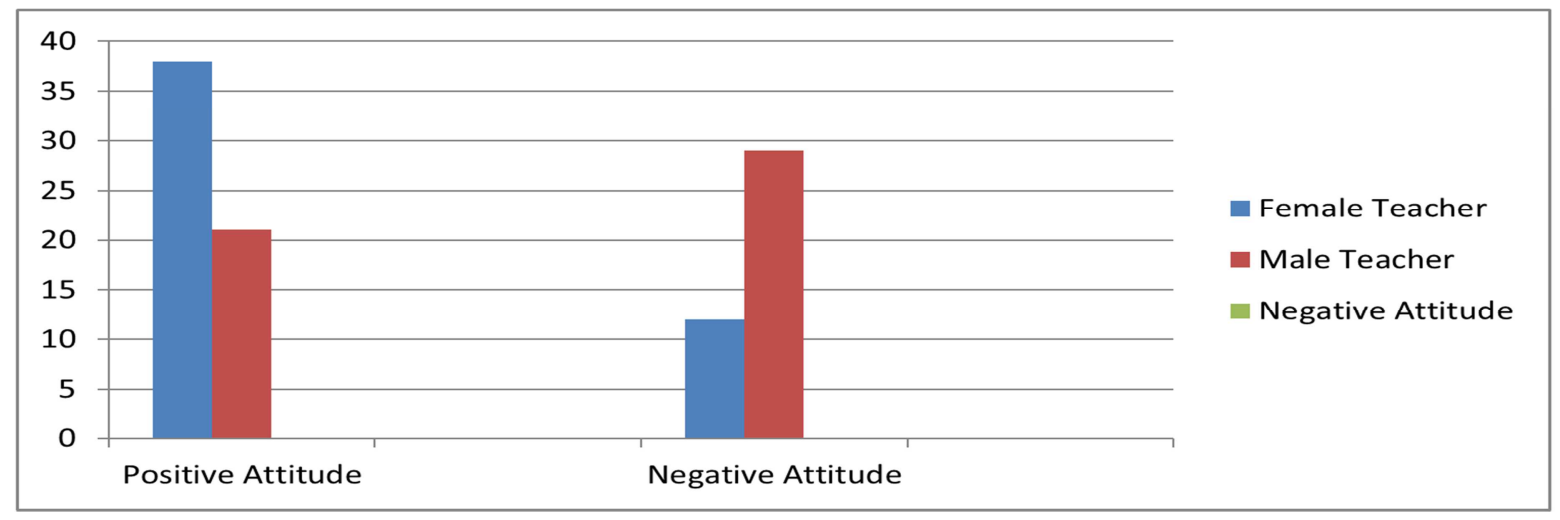

Figure 2. The graph showing percentage distribution of teacher attitude according to the type of school and gender.

3. Such as a result of the research, it found that 75 per cent of female teachers (38 teachers) received positive attitude and 25 per cent (12 teachers) attitude of female teachers. Teachers have 42 per cent (21 teachers) attitudes positive and 58 per cent (29 teachers) teachers' attitudes were negative.

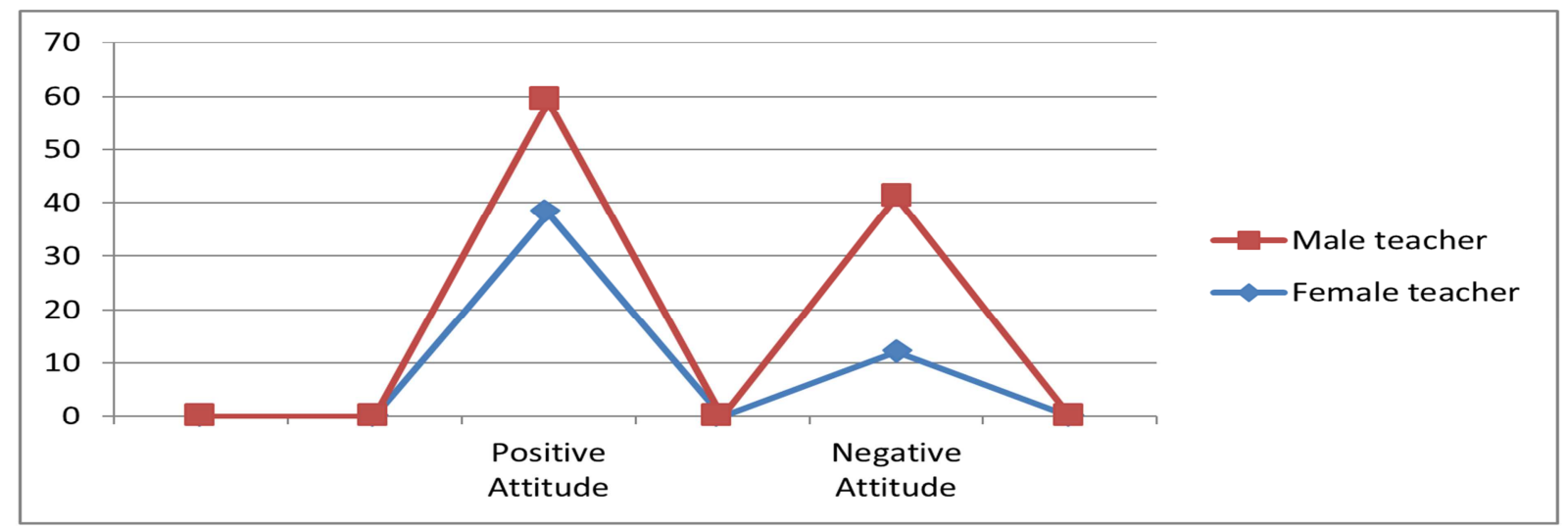

Figure 3. The graph showing percentage distribution of female teacher according to type of school.

4. Because of the research, it found that $78 \%$ (19 teachers) female teachers of the government school were positive and $22 \%$ ( 6 teachers) attitude of female teachers got negative. Teachers in the government school of $71 \%$ (18 teachers) have positive attitude and $29 \%$ (7 teachers) teachers have negative attitude. In female teachers of non-government schools $49 \%$ (12 teachers), positive attitude of female teachers and 51\% (13 teachers) attitude of female teachers was negative. Attitudes of $45 \%$ teachers (11 teachers) teachers in non-government schoolteachers and positive attitude of $55 \%$ (14 teachers) teachers got negative. 


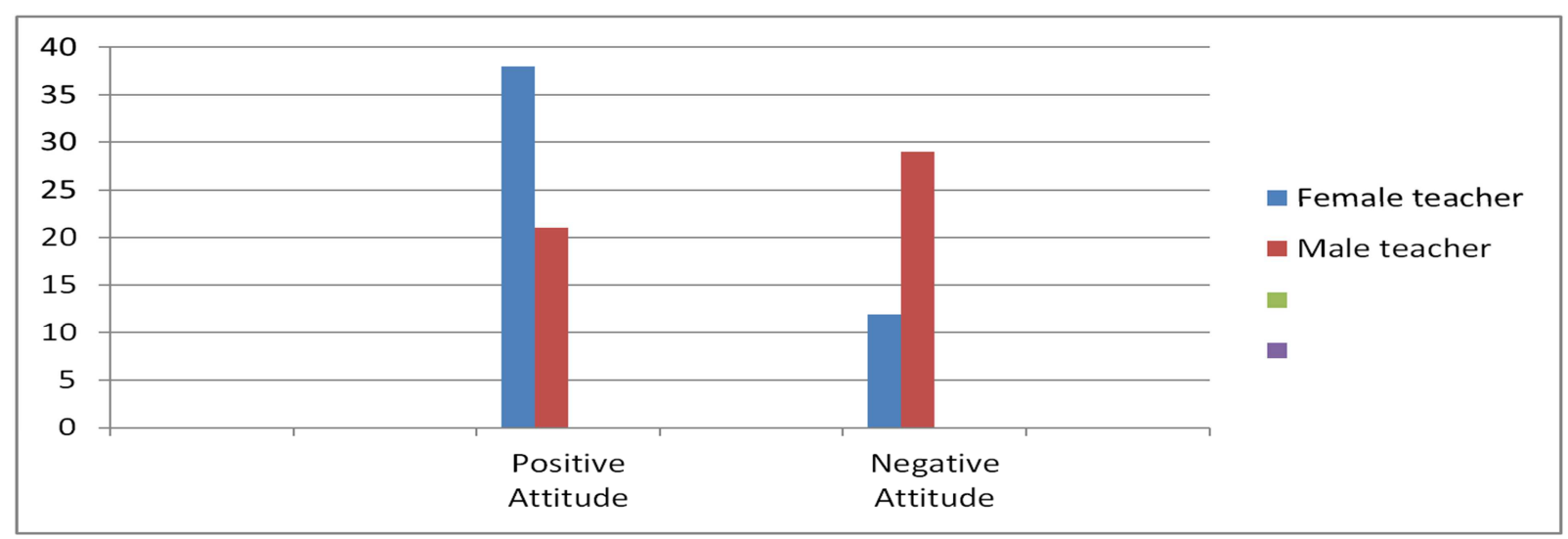

Figure 4. The graph showing percentage distribution of female and male teacher according to type of school, gender and level of attitude.

\subsection{Discussion}

Based on the results of the research, it will say that the teacher's attitude of various higher secondary level teachers has founded general, but after getting results, it will be said that the attitude of the female teachers is the attitude of male teachers found more positive. The attitude of government teachers and teachers has received more positive than nongovernment teachers and teachers. In addition, the attainment of government male teachers has received less positive than non-government teachers' aptitude. In addition, the attitude of female teacher of the state-level schoolteacher has received more positive, other than female teachers. In conclusion, uniformity was finding in the attitude of education of all students and teachers of divine students.

The above research results have received, the details of some research related to it are giving below, e.g. Martin (2013), as their research result said that normal school teacher attitude towards children with disability is find normal. Along with this, Oppenheim (2012) said through his research that women's attitude is positive compared than men. Which has been reflected in the research presented by me, when we got the middle of the male teachers and women's teachers, the meanings of the female teachers received more than the meanings of male teachers who demonstrate that the attitude of female teachers is the attitude of male teachers more than. In addition, Kearn (2006) in his research results stated that the attitude of ordinary class teachers is normal for the people. However, they need training so that their attitude changes further. The results obtained from these researches prove the results obtained by research done by me.

\section{Conclusion}

After explaining of the results to presented in the research, we will conclude that in the research, all the teachers, who have joined in the form of usability have received general attitude towards the education of the child with disability students. Since, the attitude of a person, as a teacher is important. because the attitude of any human being is important to a person or person, in any way, any man's manifestation is only two forms as positive and negative forms, but when a person. If the perfection becomes permanent to a particular person to person, then it becomes part of his personality. By the way, the transformation is not permanent but the change is pure, but when it becomes a part of personality then the perception becomes permanent. In keeping with this in mind, we will say that the teacher's attitude is negative towards a child, giving them a positive form through training to done. Which teachers cannot become part of their personality towards the education of the division, because education is a tripled process, in which the teacher acts as an important role. As a result, we will say that teachers need training, even if the teacher's attitude has received in general but at many points fewer than usual. Finally, the type of disability and the degree of its visibility influences the attitudes and perceptions of teacher's towards their children with disability. In this research, the teachers have more positive attitude toward children with locomotor disability, compare to children with visual disability, hearing disability and intellectual disability. Equally negative attitude was show by private school male teachers in senior secondary level toward children with locomotor disability, because the teachers believe toward children with locomotor disability has, its student has not mental problem, only physical problem, so they learn equal to general students.

\section{Recommendations}

Given the limitations of the current study, a clear future direction is to collect inductive and longitudinal data on the development and change of teachers' attitude towards children with disability. Based on the results obtained, it is suggested that;

1. Inclusive education should be imparted training of inclusive setting teaching during teacher training.

2. To change the attitude of teachers, in-service training should be arranged from time to time.

3. Every teacher should be given training in teaching in an inclusive classroom.

\section{Author Contributions}

Through research, the author has find out to the main problems that affect teacher's attitude, as well as research has 
shown that the nature of school, teachers' experience, gender and training on teaching with children with disability. What type of attitude is there for the education of children, the results obtained from the research show that the education of children with physical disabilities? In particular, experience, gender and training have an impact on attitude, these results will act as a guide for future research.

\section{Limitation of Research}

This research confined to teachers of class $11^{\text {th }}$ and $12^{\text {th }}$.

\section{Acknowledgements}

The authors gratefully acknowledge to create of tools in this research self-development and conducted to data face by all teachers.

\section{References}

[1] Aiden, H. and A. McCarthy. (2014). Current attitudes towards disabled people, Scope is a registered charity, number 208231. Copyright Scope May 2014, Retrieved from: $\mathrm{http} /$ wwww.research-information.bristol.ac.uk/currentattitudes-towards-disabled-people.

[2] Al-Faiz, H. (2007). Attitudes of elementary school teachers in Riyadh, Saudi Arabia toward the inclusion of children with autism in public education. ProQuest Information \& Learning) Dissertation Abstracts International Section A: Humanities and Social Sciences, 68 (4), 1403-1403.

[3] Avissar, G., Reiter, S., \& Leyser, Y. (2003). Principals' views and practices regarding inclusion: The case of Israeli elementary school principals. European Journal of Special Needs Education, 18 (3), 355-369.

[4] Baron, R. A., \& Byrne, D. (1994). Social psychology: Understanding human interaction, 7th ed., Boston, MA: Allyn and Bacon.

[5] Behera, S. K. (2015). Educational Thoughts of Dr. Sarvapalli Radhakrishnan. Assam, IRJIMS, 4 (1) 12-18.

[6] Boer., A., d., S. Jan Pijl, W., Post and A., Minnaert (2012). Which variables relate to the attitudes of teachers, parents and peers towards students with special educational needs in regular education? Netherlands, Educational studies, 4 (2) pp 82.

[7] Das, B. N. (2007). Vishishtha Balako ke liye Shiksha. Delhi, Ajanta publication, pp-123-228.

[8] Eichinger, J., Rizzo, T., \& Sirotnik, B. (1991). Changing attitudes toward people with disabilities. Teacher Education and Special Education, 14, 121-126.

[9] Eiserman, W., Shisler, L. \& Healey, S. (1995). A community assessment of preschool providers' attitudes toward inclusion. Journal of Early Intervention, 19 (2), 149-167.

[10] Elias Avramidis \& B. Norwich. (2010). Teachers' attitudes towards integration / inclusion: a review of the literature, European Journal of Special Needs Education, DOI: $10.1080 / 08856250210129056$.
[11] Fragoudaki, A., \& Dragona, Th. (1997). Introduction, In Fragoudaki, A., \& Dragona, Th. (Eds). What is our homeland; Ethnocentrism in education, 13-26, Athens.

[12] Friske, S. T., \& Taylor, S. E. (1991). Social Cognition: From Brains to Culture, 2nd edn. New York: Random House.

[13] Grames, M. \& C. Leverentz. (2010). Attitudes Toward Persons with Disabilities: A Comparison of Chinese and American Students. Journal of Undergraduate Research, Retrieved from https://www.uwlax.edu/urc/jur-online/PDF/2010/gramesleverentz. 20.11.2016.

[14] Kalam. (2003). Samaveshi Shiksha aur Shikshak. Khoje aur Jane, Udaypur, Vidya Bhavan Society, 7, pp-34.

[15] Kern, E. (2006). Survey of Teacher Attitude Regarding Inclusive Education within an Urban School District. School Psychology Commons, Retrieved from: http://digitalcommons.pcom.edu/psychology_dissertations, 16 . 06.2016 .

[16] Koster, M., Nakken, H., Pijl, S. J., \& Van Houten, E. (2009). Being part of the peer group: A literature study focusing on the social dimension of inclusion in education. International Journal of Inclusive Education, 13 (2), 117-140.

[17] Krahe, B. and C. Altwasser. (2006). Changing Negative Attitudes towards Persons with Physical Disabilities: An Experimental Intervention. Retrieved from: http://onlinelibrary.wiley.com/,18.06.2016

[18] Lindsay, G. (2007). Educational psychology and the effectiveness of inclusive education/ mainstreaming. British Journal of Educational Psychology, 77 (1), 1-24.

[19] Martín, A. R. and Emilio Á. (2013). Development and validation of a scale to identify attitudes towards disability in Higher Education. ISSN: 0214-9915, retrieved from http://www.psicothema.com. 28.09.2016.

[20] Ministry of Human Resourse Development. (2016). Educational Statistics At A Glunce. New Delhi, Government of India, pp 1 to 56, http://www.mhrd.gov.in, 22.11.2016

[21] N. C. E. R. T. (2006). Position paper national focus group on education of children with special needs. New Delhi, NCERT.

[22] NUEPA. (2014). Education for All Toward Quality with Equity India. New Delhi, Government of India, MHRD. Retrieved from: http://mhrd.gov.in/nep-new, Pp 2 to 156.

[23] Oppenheim, A. N. (1966). Questionnaire design, interviewing and attitude measurement. London and New York, Pinter Publishers, Retrieved from: https://www.kth.se/social/. 12.04.2017.

[24] Ram, (2014) Vikalango ki shiksha, Khojo aur jano, 24 (8) 2430.

[25] Rix, J. (2009). A model of simplification: The ways in which teachers simplify learning materials. Educational Studies. 87, 94-97.

[26] Social statistics Division. (2016). Disable person of India: At statical profile. New Delhi, GOV, India. Retrieved from: http://mospi.nic.in. Pp 1 to 341 .

[27] UNESCO. (2009). Toward inclusive education for children with disabilities: guideline. Bangkok, unesco, pp 43-58. 
[28] Vlachou, A. (2014). Pedagogy of Integration [Academic Course Notes]. Umiversity of Thessaly, Department of Special Education, Spring Semester 2014-2015. Volos.

[29] Vignes, C., Godeau, E., Sentenac, M., Coley, N., Navarro, F., Grandjean, H., \& Arnaud, C. (2009). Determinants of students' attitudes towards peers with disabilities. Developmental Medicine \& Child Neurology, 51 (6), 473-479.
[30] Zoniou-Sideri, A., Nteropoulou-Nterou, E., \& VlachouBalafouti, A. (Eds) (2012). Disability and education policy, Athens: Pedio.

[31] Zoniou-Sideri, A., \& Vlachou, A. (2006). Greek teacher's belief systems about disability and inclusive education. International Journal of inclusive Education, 10 (4/5), 379394. 